\title{
Making Subject Specialists Available for Service
}

Mr. Gorchels is acting assistant director of libraries, State College of Washington, Pullman.

$\mathrm{I}^{\mathrm{F}}$ F TWO ARE GOOD, are eight better? In short, that is the question being put to the test in the library of the State College of Washington.

The State College of Washington possesses one of the first and finest of the new post-war library buildings constructed especially to offer the advantages of library service based on the subject-divisional-library type of organization. The new $\$ 3,000,000$ building, ${ }^{1}$ now in its fourth year of service to the 5600 students and faculty of the college, has been an important factor in enabling the director of libraries, G. Donald Smith, and the library staff to develop a pattern of service which is designed to make the library a very active participant in the instructional and research programs of the college.

The characteristics and the theoretical advantages of the subject divisional plan have been well expounded in library literature, ${ }^{2}$ and at least one very good detailed study of a subject divisional unit has ap-

1 "Modular Library Under Construction," Architectural Record, CIV (July, I948), $102-9$.

${ }^{2}$ Ralph E. Ellsworth, "Colorado University's Divisional Reading Room Plan: Description and Evaluation," COLIEGE AND RESEARCH IIBRARIES, II (March, I94I), 103-9, 192. W. H. Jesse, "Divisional Organization," Journal of Higher Education, XV (December, I 944) 459-64. John D. Chapman, Ralph H. Hopp, Arthur J. Vennix and Kathryn R. Renfro. "The Divisional Library at Nebraska: Two Aspects," COLLEGE AND RE. SEARCH LIBRARIES, XV (April, 1954), I48-57. G. Donald Smith, "The Divisional Organization of the Reader Services at Washington State College," Changing Patterns of Reference Service. (Seattle: University of Washington, Bureau of Governmental Research and Services, 1953), I I-19. peared in the pages of this journal. ${ }^{3}$

Yet, investigation indicates that libraries have hesitated to develop the relatively pure type of subject divisional organization which should more clearly determine the functional advantages and disadvantages of this type of organization. This situation prompts the question of why only one or two librarians with a special subject interest are put into a divisional library which inevitably has seven or more special subjects. Certainly, it would be difficult to test fairly the value of subject specialists in reader service activities in a science divisional library, for instance, if the science library had specialists only in physics and zoology. What happens to botany, chemistry, mathematics, agriculture, and engineering? Again, it would be difficult to fairly test the value of subject specialists in a humanities divisional library, say, if the humanities library had librarians with special subject interest in only American literature and fine arts. What happens to foreign languages, music, religion, and philosophy? Finally, it would be rather difficult to test fairly the value of subject specialists in performing operations involved in the organization of resources in, say, a social science divisional library, if the social science library had librarians with special subject interest in only history and economics. What happens to sociology, education, psychology, business, and political science?

Consequently, in the library at the State

\footnotetext{
3 Percy C. Morrison, "Variation of the Subject Divi. sional Plan at Oregon," collEGE AND RESEARCH LIBRARIES, XIV (April, I953), 158-63.
} 
College of Washington, varying numbers of librarians with appropriate special subject interests have been assigned to each of the three divisional libraries. At this time, eight professional librarians are in the social science library, six professional librarians are in the science library, and five professional librarians are in the humanities library.

That adds up to nineteen professional librarians! What do they all do? Obviously, they have duties which are considerably more varied than those of a reference librarian in the average medium-sized university library reading room. As has already been implied, of course, most of these nineteen professional librarians with special subject interests have three-fold responsibilities: (I) they participate in reader service work. (2) they have a role in the selection of the library's resources, and (3) they have duties of major importance involving the cataloging and organizing of the library's resources.

Basically, it is felt that the worth of the subject specialist is greatly increased as he participates in the organization of the library's resources (especially in subject cataloging and classification) as well as participating in book selection and service to readers' activities. It is this decentralization of cataloging, in the broadest sense of the term, which makes possible the highly desirable situation of having more subject specialists available for reader service. For, when the large staff of catalogers needed in a university library is taken out of the behindthe-scenes cataloging department and assigned to divisional library posts, each divisional library gets a substantial increase of staff. Admittedly, the cataloging work still must be done. But why not have it done in the appropriate divisional library in direct and constant contact with reader service requirements? It is important to make the library's subject specialists available for the maximum amount of reader service work as well as for selection of resources duties and cataloging and bibliographic work in his special subject area. Thus, it is advantageous for him to be physically located in the appropriate divisional library area if he is to have a full opportunity to get to know the readers (students and faculty) and the needs of these readers who come to this divisional library.

This idea of combining service to readers with cataloging is not very original, of course. The idea has been considered by a number of librarians over the years, and a concrete proposal by John J. Lund appeared in print in $1942 .{ }^{4}$ Other librarians, such as Raynard Swank ${ }^{5}$ and G. Donald Smith have in recent years presented refinements. Yet, Morrison ${ }^{7}$ summarized the existing situation very well when he said: "Some adherents of the subject divisional plan have modified the plan to the extent of centralizing cataloging, or circulation, or government and international documents, or any combination of these library functions, or all of them." In other words, libraries are very slow to break with past patterns of centralization of many of the traditional functions of university libraries.

However, at the State College of Washington, in addition to carrying on the experiment of decentralized cataloging, the library administration has also rejected the traditional separate and special documents room and the special reserve reading room. The concept of establishing special library functions rooms is not considered to be in the best interest of over-all service. A large college or university library is intrinsically a

4 John J. Lund, "The Cataloging Process in the University Library: A Proposal for Reorganization," colLEGE AND RESEARCH LIBRARIES, III (June, I942), 2 I 2-

I8. R. C. Swank. "Subject Cataloging in the SubjectDepartmentalized Library." In Jesse H. Shera, and Margaret E. Egan, eds. Bibliographic Organization. (Chicago: University of Chicago Press, I951), 187. r9g. ${ }_{\text {G. Donald Smith, op. cit. }}$ G. Donald Smith, op. cit.
Percy C. Morrison, op. cit. 
very complex institution in itself. It is no easy matter to orient the average student to the point at which he can use the library efficiently and confidentially. In this respect, the subject divisional type of organization has real advantages. It is relatively easy for the student to learn that when he wants materials and services in the social sciences, for example, he should go to the social science library. Something concrete is accomplished. However, if special rooms, such as a documents room or reserve book room, are set up, there is an increase in the likelihood that the student will be overwhelmed and confused. Also, at times he might be given the "run-around." He can be referred from one room to another and from one person to another almost ad infinitum.

On the other hand, it is recognized at the State College of Washington that some activities are so mechanical that professional librarians need not be involved except in broad policy making. The more routine "technical processes" of ordering new books (after professional selection), checking invoices and approving payment, catalog card production, card filing, book marking and pocketing, and the sending and receiving of binding are centralized in the library's technical service division. It is likely that even more technical and predominantly clerical activities can be advantageously transferred to a centralized area.

It would be shortsighted to fail to acknowledge at least three major problems which challenge the success of the pure subject divisional type of organization in the library. First, how can a library successfully recruit and develop the very essential subject specialists? Secondly, how can older staff librarians who have worked only the traditional way in the traditional library set-up as catalogers or reference librarians exclusively be integrated effectively into the new type organization? Thirdly, how can subject specialization be combined with library technical duties in a way to assure efficient, productive work from each librarian? These problems can be recognized and defined, but not much in the form of instructional answers can be offered now.

As for Problem I, in these times, admittedly, the library cannot very successfully outstrip the competition for subject specialists. Therefore, specialists on the doctoral level have been rare in the library. But by offering opportunities for additional subject development and by having a fairly good salary scale, the library has been successful in engaging specialists on the master's degree level. Furthermore, the device of assigning a special subject interest to each librarian has also been found to be salutary.

Concerning Problem II, the older staff members themselves have made a very earnest effort to serve in their new roles. Adaptation has been very difficult in some cases, of course, but the library administration has not been inflexible. A few compromises have been made for the benefit of two or three persons who might otherwise be too unproductive.

Problem III, concerning ways and means of successfully combining subject specialization with library technical duties, remains most imposing. It is too early in the development of the plan to claim any degree of success. But the willingness of most good staff members to accept the prescribed variety of activities and duties is the most encouraging factor at this time.

In summary, the pure subject specialization plan has been developed for the library of the State College of Washington in the belief that the plan gives better service to the students and faculty. By participating in reference service, in the selection of the library's resources, and in the organization of the library's resources, each subject specialist-librarian is able to make a more complete contribution to the services of the library. 